\title{
Determinants of Rural Households' Participation in Microfinance Program: The Case of Omo Microfinance Institution, Sodo Woreda, Southern Nations Nationalities, and Peoples Regional State, Ethiopia
}

\author{
Tadele Alemayehu \\ School of environment, gender and development studies, \\ Hawassa College of agriculture, Hawassa University
}

\begin{abstract}
In a subsistence agriculture and low income countries like Ethiopia, where rural households dominate the overall national economy, who are facing with shortage of financial resources not only to purchase productive agricultural inputs but they also need to participate in income generating activities. Since 1996 Microfinance institutions have made significant assistance to the livelihoods of many people through the provision of financial and supporting services to the poor, especially low income households in rural environments. This study was conducted to assess the determinants of rural household participation in microfinance program and its impact on their income and asset building in Sodo Woreda. Both primary and secondary data were used for the study. Multi-stage stratified sampling technique employed. Primary data were collected from a total of 190 rural households of which 80 were participants and 110 were non-participants in microfinance programs using systematic and simple random sampling technique. Descriptive statistics and econometric model were used for analyzing the data. Descriptive and test statistic were computed to describe demographic, socio-economic and institutional characteristics and living condition. A propensity score matching method was employed to analyze determinants of rural households' participation in microfinance program and its impact on income and asset holding of participant households. The result of the descriptive statistics indicate that participants were Participant groups were better off agricultural input usage, clothing status of adult members of the household, annual income earning, amount and quality of food consumed during last five years, total expenditures and total livestock holding. The result of the propensity score revealed that family size, level of education and frequency of extension contact significantly and positively influenced the participation of rural households in microfinance program whereas number of dependent members, application procedure for credit, perception on risk of borrowing and distance of household's residence from office of Omo Microfinance Institution had significantly and negatively influenced the participation of rural households in microfinance program. The average treatment effect on the treated showed that program participant households earned an average income of 2716.68 Birr and had an average total value of non-livestock asset of 3079.38 Birr and 2.46 TLU of livestock which were significantly greater than that of non-participants. Similarly, the result of descriptive statistics revealed that participants were better off in earning total income, amount, and quality of food consumption and clothing status of adult member of households as compared to non-participants. Therefore, Omo Microfinance Institution and other concerned stakeholders should expand access of microfinance program to rural households in livelihood enhancement and poverty reduction endeavors.
\end{abstract}

Keywords: Microfinance, impact, income, asset holding and propensity score matching.

DOI: $10.7176 / \mathrm{JESD} / 11-1-03$

Publication date: January $31^{\text {st }} 2020$

\section{INTRODUCTION}

\subsection{Background of the Study}

There is recent global agreement that microfinance institutions (MFIs) are good instruments to fill the gap of conventional banks' limitations in reaching the poor and the vulnerable non-poor with banking services. They are considered as one of the most effective interventions for empowering the poor in their economic and social involvements. That is, through these MFIs, the poor are able to access financial services, which previously were exclusively available to the upper-income population. The basic idea behind such intervention is that access to micro-finance services such as savings, credit, and micro-insurance to the poor could help them, among others, to expand their businesses that will allow them to pull out of poverty (Asmamaw, 2014; Shannon et al., 2007).

Microfinance is typically viewed as an economic development strategy, and it is a particularly relevant approach in countries where disadvantaged groups tend not to benefit from involvement in the conventional bank. In most developing nations, the majority subsists on income from microenterprise activities; the microenterprise sector, is estimated to account for $20 \%$ to $70 \%$ of all employment in many developing countries, illustrating the importance of the informal economy in the subsistence of impoverished populations throughout the world (Bigsten et.al, 2007). Microfinance is a logical approach to development because it functions at the grassroots level, can be sustainable, is capable of involving large segments of the population, and builds both human and productive 
capacity (Shannon et al., 2007).

According to World Bank (2015), Ethiopia is one of the poorest and the largest populated countries in Africa. Its total population was estimated to 99,390,750; its economy is based on agriculture, which accounts for more than $40 \%$ of GDP, $80 \%$ of exports, and $80 \%$ of total employment. Shortage of finance is particularly acute among the millions of farmers. They need to buy improved agricultural inputs and implements to increase their income and break the perpetuity of the poverty cycle they are entangled with. But they cannot do this because they lack finance. The credible solution for this seems to improve vastly farmers' access to rural financial services. It is unlikely to achieve sustained agricultural development without sustained use of improved agricultural technologies by small farmers through providing rural financial services (Amogne, 2014; Shimelis and Zahidul, 2009).

Microfinance intervention is taken as a strategy to overcome the constraints of convectional bank and it is seen as one of the most efficient instrument to promote economic development, livelihood improvement and diversification and infighting poverty in poorer countries (Asmamaw, 2014; Wolday, 2007). Based on this ideology, the federal government of Ethiopia formulated a rural development strategy and underlined the role of rural finance/microfinance for the overall development of the agricultural and micro and small enterprise sector. And also microfinance program has been found to be a critical instrument in order to improve the livelihood of poor people. The prevalence of poverty in Ethiopia is high because of lack of assets, employment opportunities, income, skill, education, nutrition, health, etc. (Wolday, 2007). As a result, it necessitates the use of microfinance as an intervention mechanism of rural livelihood enhancement and poverty reduction endeavors.

The formal microfinance in Ethiopia started in 1994. In particular, the Licensing and Supervision of Microfinance Institution Proclamation No. 40/1996 indicate that; the government encouraged the spread of microfinance institutions (MFI) in both rural and urban areas as it authorized them among other things, to legally accept deposits from the general public (hence diversity sources of funds), to draw and accept drafts, and to manage funds for the micro financing business (Ayalew, 2014). In 2014, there were 31 licensed micro finance institutions operating in Ethiopia where most of them have evolved either from the credit component of the governments or NGOs credit scheme. The microfinance sector plays a major role in providing credit services to the poor in rural and urban areas (Bekele and Dereje, 2014).

\subsection{Statement of the Problem}

Microfinance has been used as a powerful tool in alleviating poverty in recent years and if it is supported by research (Ravallion, 2005). The prevailing operation of the formal or conventional financial institutions in many low-income countries such as Ethiopia is inefficient in providing sustainable credit facilities to the poor. Therefore, targeting credit to the poor is found to be one of the many instruments for poverty reduction. The main objective of almost all microfinance institutions in Ethiopia is to deliver financial services to the poor. Microfinance became one of the important tools of reaching the poor who had very limited access to the formal financial sector. The provision of financial services to the poor has increased through microfinance institutions in a short period of time in Ethiopia. However, Ethiopian microfinance institutions are faced with many problems. Some of these are low outreach, limited funding alternatives, limited financial products, lack of research to understand client needs and weak internal control system (Abebe, 2006; Wolday, 2007).

About 33\% of Ethiopians live below the international poverty line (US\$1.25 per day) (WB, 2015; UNDP, 2014). Those peoples who live below the poverty line lacks adequate means to have access in conventional financial institutions the reason being that they don't have collateral or are not trust worthy. Their only solution as a way forward of then was traditional money lenders who charged high interest rates. As a matter of fact microfinance came in as relieve to the poor as the only formal financial institution that can lend money to them. As earlier mentioned, the establishment and the growth in microfinance is indirectly a tool to eradicate poverty. Government of less developed countries have frequently practiced the policy of providing credit with low interest rate to the agricultural sector through financial intermediaries, expecting that credit would lower dependency on the rural money lenders (Martina et al., 2008). According to Achamyeleh (2011) microfinance contributes to the development of human, social and physical capital to the poor. Despite of this, European Academic Research argued that some researchers conducted in microfinance showed that people who access the service of microfinance runaway from poverty and their living condition were improved both in rural and urban (Fareed et al., 2014)

Despite the growth of microfinance programs specifically designed to target poor are still not very widespread. It is still being debated whether reaching the poorest with these programs is even desirable. An added concern is that funds are targeted to help the poor and /or landless, but there are generally little available resources to help small and medium size farmers from falling deeper into poverty. A study of thirteen (13) MFIs in seven developing countries were taken (Mosely and Hulme, 2004 cited in Haftom, 2011) and found that the evidence of a trade-off between reaching the very poor and having substantial impact on household income and consumption. They found that programs that targeted active poor households (those near the poverty line level) had a greater impact on household income. Those below the poverty line were not helped much and the very poorest were somewhat 
negatively affected.

Sodo Woreda is just like other areas of Ethiopia; there are several microfinance institutions and Omo Microfinance Institution (OMFI) is one of them that deliver microfinance service to the society in order to reduce shortage of financial capital that is required to acquire improved agricultural technologies that would increase production and productivity. Furthermore, OMFI deliver credit and saving service to run non-farm activities which contribute for the improvement of the lives of rural household.

Even though it is generally believed that microfinance programs are an indispensable part of input packages that are prescribed as part of agricultural investment projects designed to introduce modern technologies and thus stimulate change and growth in agriculture and increase income which create opportunities for livelihood enhancement, there were very few studies so far conducted with respect to the factors affecting rural households' participation in microfinance program and the impact of OMFI microfinance program on livelihoods of rural households in general and income, and asset holding of rural households in particular in Sodo Woreda. Therefore, it is imperative to undertake this study to see rural households' participation in OMFI microfinance program and its impact on their livelihood in general and incomes and asset holding in particular.

\subsection{Objectives of the Study}

The general objective of the study was to assess the factor affecting rural households' participation in OMFI microfinance program and its impact on their income and asset holding in Sodo Woreda.

Specific objectives were:

1. To identify factors affecting participation of rural households' in microfinance programs; and

2. To evaluate the impact of OMFI microcredit on rural household income and asset holding.

\subsection{Research Questions}

The study has attempted to answer these research questions.

1. What are the factors affecting participation of rural households in microfinance program?

2. What changes in incomes and asset holding has the OMFI microcredit brought in the lives of rural households?

\section{LITERATURE REVIEW}

\subsection{Definitions and Concepts of Microfinance}

Microfinance is the provision of financial services to low income poor and very poor self-employed people (Otero, 1999). These financial services according to (Ledgerwood, 1999) generally include savings and credit but can also include other financial services such as insurance and payment services. (Schreiner, 2001) support this view by defining microfinance as "the attempt to improve access to small deposits and small loans for poor households neglected by banks." Therefore, microfinance involves the provision of financial services such as savings, loans and insurance to poor people living in both urban and rural settings who are unable to obtain such services from the formal financial sector.

Moreover, Microfinance is an economic development approach that involves providing financial services, through institutions, to low income clients. The services provided by the Microfinance Institutions (MFIs) include credit, savings and insurance services. MFIs also provide social intermediation services such as training and education, organizational support, health and skills in line with their development objectives (Robinson, 2007). Further, Microfinance Institution (MFI) is an organization, engaged in extending micro credit loans and other financial services to poor borrowers for income generating and self employment activities. A MFI is not part of the formal banking industry or government (Alexander, 2011).

Related concepts to Microfinance are micro savings, microcredit, micro insurance and MFIs.

Micro-Savings is also a microfinance service that allows impoverished individuals to safeguard money and other valuables items and even earn interest. It allows a lump sum to be enjoyed in future in exchange for a series of savings made now (Arytery, 2008).

Microcredit is the name given to small size loans made to poor people who are regarded as bad financial risks, by conventional banks, as they have insufficient savings or assets to obtain a loan. In relation to this, flexible and easy to recognize regulations on loans, small scale activities based on local conditions and needs, clients are small entrepreneurs and low-income households used to generate income (Bliss, 2005).

Microfinance Institutions (MFIs) refers to the provision of formal financial services to poor and low-income (in particular, those who have no collateral) people, as well as others systematically excluded from the financial system. However, microfinance embraces not only a range of credit products (for business purposes, for consumption smoothing, to fund social obligations, for emergencies, etc.), but also savings, money transfers, and insurance (CGAP, 2013). They have played an active role in reducing or protecting the low income earners against vulnerability. This is done by providing credit for increasing income earning opportunities and through providing savings services to build up resources that can be drawn down in cases of emergencies (Bliss, 2005). 
Participants are rural households who have been participated in OMFI microfinance program for $\geq 5$ years. Non-participants are rural households who have not been participated in OMFI microfinance program yet. Qocho is a food staff of high and mid land society of the study area which is prepared from "enset".

\subsection{The Emergence of Microfinance}

The origin of microfinance as we know it today lies in the establishment of the Grameen Bank in Bangladesh by Muhammad Yunus in 1976. Since the founding of the program, when a loan of $\$ 27$ was provided to 42 borrowers, and the current state of the bank with a gross loan portfolio of $\$ 13.14$ billion and almost 86 million active borrowers lies an important development in the field of microfinance (MIX market, 2014). The term 'microcredit' was first coined in the 1970 s to indicate the provision of loans to the poor to establish income generating projects, while the term 'microfinance' has come to be used since the late 1990s to indicate the so-called second revolution in credit theory and policy that are customer centered rather than product centered. But the terms 'microcredit' and 'microfinance' tend to be used interchangeably to indicate the range of financial services offered specifically to poor, low income households and microenterprises (Morduch and Haley, 2004). The microfinance institutions help the poor to start their own initiatives and to build assets for their economic security. Conventional financial institutions such as banks fail to lend money to the poor for many reasons. Hence, the poor rarely have a chance to get financial support from microfinance institution formally (Rahel, 2011).

The challenge of reducing poverty and improving living conditions for the poorest population is a formidable one. The betterment of poor people requires an effort that spans all sectors of the economy and may not be easy to achieve through economic growth alone. Improved access to financial services helps poor people by enabling payment transactions then bring them into the formal sector (Bekele and Dereje, 2014). Financial services enable poor people to use profitable business opportunities and raise earnings. Since poor people often have insufficient traditional forms of collateral to offer, they are often excluded from financial markets (Ayalew, 2014). He also point out, the formal financial institutions were relevant to extend credit facilities to the poor for fear that loans would not be repaid and poor borrowers faced high transaction costs when they sought loans from formal financial institutions. The costs included time, travel and paperwork involved in obtaining credit.

\subsection{The Role of Microfinance in the Economy}

Globally, microfinance has become a major technique in the last three decades in providing collateral-free loans to the poor. It is playing a significant role in alleviating poverty household, economic upliftment, and creating alternative livelihoods Microcredit is playing a significant role in socio-economic development, especially poverty reduction, by improving households' economic status, increasing living standards, empowering rural women, creating self-employment, and ensuring better education and healthcare (Zahidul and Shimells, 2009). In a nutshell, improved access to financial services can have two principal effects on household outcomes. First, it can raise the expected value of income and therefore of consumption and future investment and asset accumulation. This is the traditional and often sole argument for provision of services by microfinance institutions. Second, it can decrease the variances of income and consumption. For the food-insecure poor, it is particularly important to reduce the down-side risk of falling below minimum levels of disposable income for consumption of food and other basic needs. They also point out that credit makes traditional agriculture more productive through the purchase of farm equipment and other agricultural inputs, the introduction of modern irrigation system and other technological developments.

According to Getaneh (2007) Credit can also be used as an instrument for market stability. Rural farmers can build their bargaining power by establishing storage facilities and providing transport system acquired through credit. Credit plays a key role in covering consumption deficits of farm households. This would, in turn, enable the farm family to work efficiently in agricultural activities. Credit can further be used as an income transfer mechanism to remove the inequalities in income distribution among the small, middle, and big farmers. Moreover, credit encourages savings and savings held with microfinance institutions that could be channeled to farmers for use in agricultural production. Credit also creates employment opportunities for rural farmers (Ayalew, 2014).

\subsection{Impact of Microfinance on Livelihoods}

A livelihood approach is a way of thinking about the objectives, scope and priorities for development. It focuses on the multiple resources, skills and activities that people draw upon to sustain their physical, economic, spiritual and social needs. Ultimately, it is an attempt to redefine development in terms of what human beings need and in terms of what they can contribute to one other's well-being (Bekele and Dereje, 2014). The concept of Sustainable Livelihood is an attempt to go beyond the conventional definitions and approaches to poverty eradication (Feigenberg et al., 2010). These had been found to be too narrow because they focused only on certain aspects or manifestations of poverty, such as low income, or did not consider other vital aspects of poverty such as vulnerability and social exclusion. It is now recognized that more attention must be paid to the various factors and processes which either constrain or enhance poor people's ability to make a living in an economically, ecologically, 
and socially sustainable manner (Martha, 2014).

The impact of microfinance program on livelihoods is focused in terms of the changes to livelihoods assets and the use of livelihood assets to cope with vulnerability. The provision of microfinance can assist the poor find the means to protect their livelihoods against shocks and to build up and diversify their livelihood activities (Johnson \& Rogaly, 1997). Chowdhury et al. (2004) argued that if microfinance is to fulfill its social objectives of bringing financial services to the poor, it is important to know the extent to which its wider impacts contribute to poverty reduction. Social networks play an important part in helping clients escape from poverty. Access to social networks provides clients with a defense against having to sell physical and human assets and so protect household assets.

MF also contributes to building up physical assets. According to Morduch and Haley clients reflected significant increases in ownership of livelihood assets such as livestock, equipment and land. They stated that this should not be surprising as poorer clients are more risk adverse and less likely to invest in fixed capital and so are more vulnerable to having to sell productive assets in the event of a shock (Morduch and Haley, 2004). MF creates access to productive capital for the poor, which together with human capital, addressed through education and training, and social capital, achieved through local organization building, enables people to move out of poverty. Concerning financial assets, MF contributes to enhance financial capital of livelihoods assets, which can be converted into other types of capital and be used for direct achievement of livelihoods outcomes.

Loans are associated with an increase in assets, when borrowers are encouraged to invest in low risk income generating activities and when the very poor are encouraged to save; the vulnerability of the very poor is reduced and their poverty situation improves (Feleke, 2011). A research conducted by Ayalew (2014) indicated that credit received from the OCSSCO in increasing the income of the households and this in turn improves the livelihood of the households. Moreover, the nutritional trends of the beneficiaries improved by consuming different varieties of food due to improvements in business profit and high income from the sales of coffee and chat financed by microfinance. Other researchers address the same conclusion. For example, Sisay (2013) concluded that microfinance program has overall positive impact on household income, asset holding and livestock holding. Another study conducted by Abera (2015) found that microcredit participant households are better off children schooling expenditure.

\subsection{Review of Empirical Literature}

Different researchers have found strong evidence that functioning of MFIs have helped the people in meeting their daily needs and at the same time building their assets. The study conducted in Bangladesh indicated that microfinance has not only helped people to develop in their material capital but also in the human capital, by better access to health care and education system, and general awareness among the people about their rights and duties towards society. One of the most important features has been the reduction of gender biased in the society. MFIs have helped women acquire assets of their own, educated them and thus gave them the right and power in the household decision making (Shkuran and Rahaman, 2011; Khan and Rahaman, 2007).

A study by Rubinstein (1993) indicated that microfinance contributes life improvement of poor people and it was a witness it change their life from acute poverty to better living condition in Bangladesh. There was a poor mat weaver caller Joygon Begum in Bangladesh and Joygon took a loan of \$65 from Gremeen Bank and used her $65 \$$ loan to buy a used sewing machine. She decided to set up a small business where she was making clothes. Her husband became a seller of these dresses in the village markets. Prior to this loan, she and her family had little to eat and not to talk of medical care; there was little or no money. There was no money to even pay the little tuition at school for kid. The family was really suffering from financial crisis. With her loan, she rejuvenated the financial situation of the whole family and from then, they were able to feed three times a day with almost a balance diet. Their kids went to school and they had saved some money for unforeseen contingencies (Rubinstein, 1993 cited in Rahel, 2011).

A study conducted by Getachew and Padma (2005) on Omo and Sidama microfinance institutions women clients in Hawassa town, Southern Nations and Nationalities People Regional State indicated that a majority of the clients are involved in the making and trading of food and food-related products. The study also witnessed there is no diversification in their business activity. The reason for this is that the production of food and related items trade involves less risk compared to other activities. The study further found that $92 \%$ of them are not very much aware that the savings are more important than credit to build their future. The researchers' explanation of this finding is that MFI's savings policy is only to cover the risk situation rather creating any element of thrift among the clients (Getachew \& Padma, 2005).

The other study was conducted on the Dedebit Credit and Saving Institution (DECSI); found that DECSI's microfinance program has had a positive impact on the livelihoods of its clients. Compared to non-clients, clients have experienced greater improvements over a decade. Their situation has improved in terms of income, consumption and assets. They also seem to be more food secure and less vulnerable to shocks and have a greater diversification in terms of income sources. The study found that the improvement in economic condition of the 
clients is a necessary condition for DECSI's program that could lead to social and political empowerment for the marginalized groups. The study also concluded that economic empowerment leads to social and political empowerment (Borchgrevink et al, 2005). On the other hand, this study also indicated the negative effects of DECSI's program. A considerable number of credit-financed ventures fail with a possible effect on indebtedness and asset depletion of clients.

Furthermore, a research conducted in Sidama zone by Abera (2015) indicated that OMFI microcredit participants got an average annual income of 6764.10 Birr per year than non-participant households and microcredit has brought significant impact on physical assets of household valued and they own 16600.67 Birr than non-participant households. Similarly, Sisay (2013) found that there was a significant difference between participants and non-participants in change of livestock holding for the past five subsequent years. He found that participants own 1.368 TLU than non-participants which was $78 \%$ greater than that of non-participants. This is in line with the objective of MFI which focuses on improving income level and asset holding of rural households.

Furthermore, Bekele and Dereje (2014) conclude that microcredit has brought positive impact on average income of borrowers. Although results differ substantially across countries and programs both in magnitude and statistical significance level, different researchers reached the same conclusion about the impact of microcredit on household income.

\subsection{Conceptual Framework of the Study}

As discussed earlier in the literature review section and as revealed in the Figure 1 below, it is anticipated that microfinance plays an essential role in improving livelihood in general and income and asset holding of beneficiaries in particular. The linkage between variables that affect rural households' probability to participate in microfinance program and outcome variables considered by the study is presented as follows.

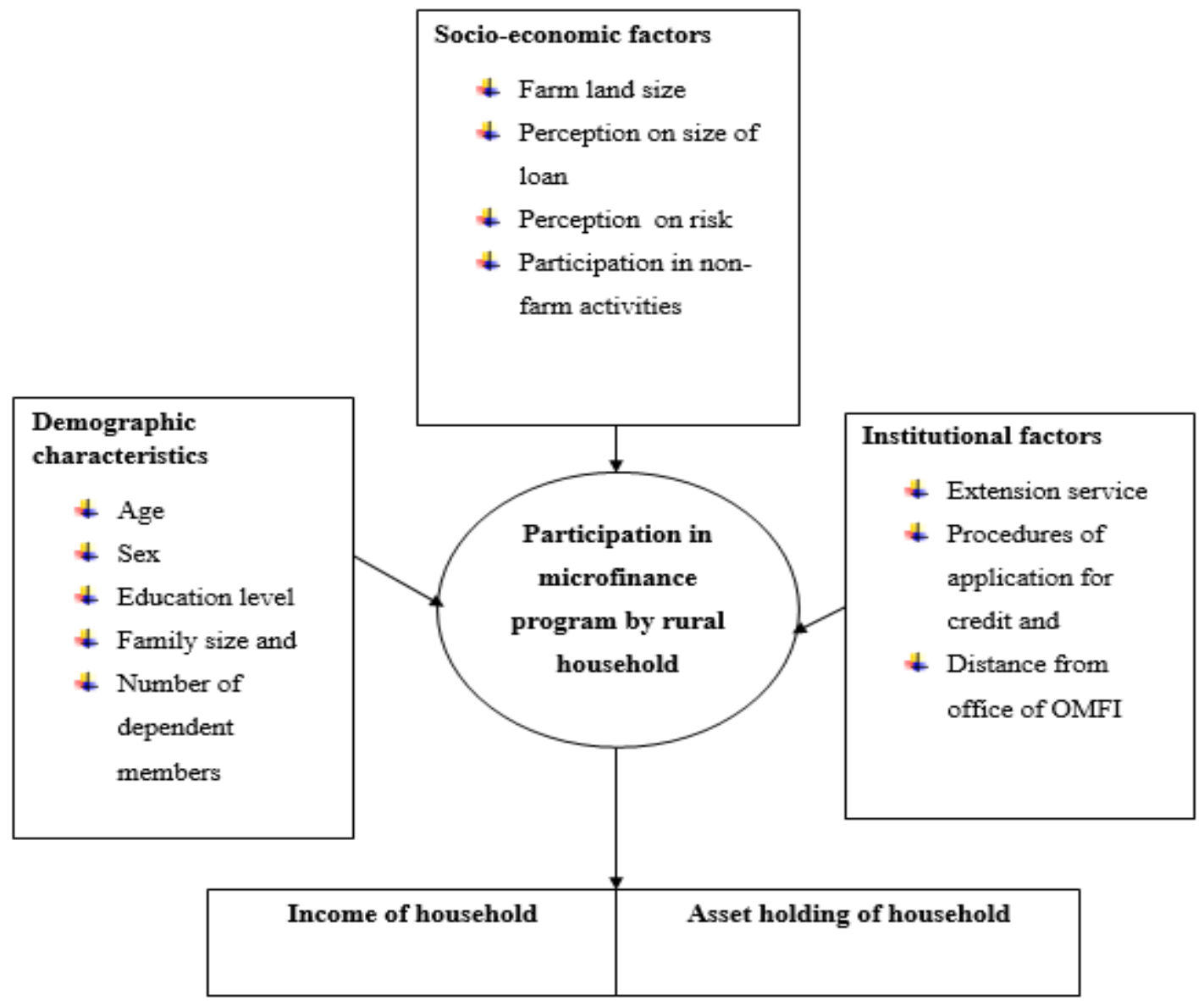

Figure 1: Conceptual framework

Source: Literature review (2016)

\section{RESERCH METHDOLOGY}

\subsection{Description of the Study Area}

Sodo Woreda is located in Guraghe zone 103 kilometers south of Addis Ababa, 193 kilometers from Hawassa, 110 kilometers from Wolkite, and 30 kilometers from Butajira. Administratively the Woreda is divided into 54 
rural and 4 Urban Kebeles. According to the report of SWOFED (2014); the total population of the Woreda was 180263 consisting of 88798 males and 91465 females. From these 17236 were urban and 163027 rural inhabitants. The Woreda has an estimated land area of $103834.3 \mathrm{ha}$. Altitude varies between 1700 and 3600m above sea level and the area is characterized by low to high land agro-ecological zones. The annual rain fall is $1021.7 \mathrm{~mm}$ with a minimum of $800 \mathrm{~mm}$ and maximum of $1200 \mathrm{~mm}$ and temperature varies between $8.6-25.4 \mathrm{c}^{0}$. Rainfall is bimodal occurring in two main growing seasons, namely the belg growing season (extending from March to May) and the "Meher" growing season (extending from June to August) (SWAO, 2018, SWOFED, 2018).

"Belg" season is a period of land preparation and planting of crops like maize, onion, garlic, sorghum and potato. During "Meher" season crops such as, burley, wheat, teff, bean and pea are grown. Teff, wheat, burley and maize are the main potential crops in the area. During "bega" (December to February), Farmers in the dega and weynadega grow enset for multi-purpose uses such as for food, animal feed, to construct traditional houses and for other purposes and prepare "qocho" from it. "Qocho" is the main food stuff of the societies" of "dega" part. In general mixed agriculture (crop and livestock production) is practiced in the study area.

In the study area there are three MFIs; Agar, Netsanet fana and Omo MFI. Agar and netsanet fana MFIs are a recently established, in 2010 and 2012 respectively (SWOFED, 2018). OMFI is established in 2002 and now a day it has a capital of around 71 million, from these 40 million in kind and 31 million in cash. It gave 22 million credits to beneficiaries and save 14 million from beneficiaries. It has 18,040 members and from these 13,573 was currently active (SWOMFI, 2018).

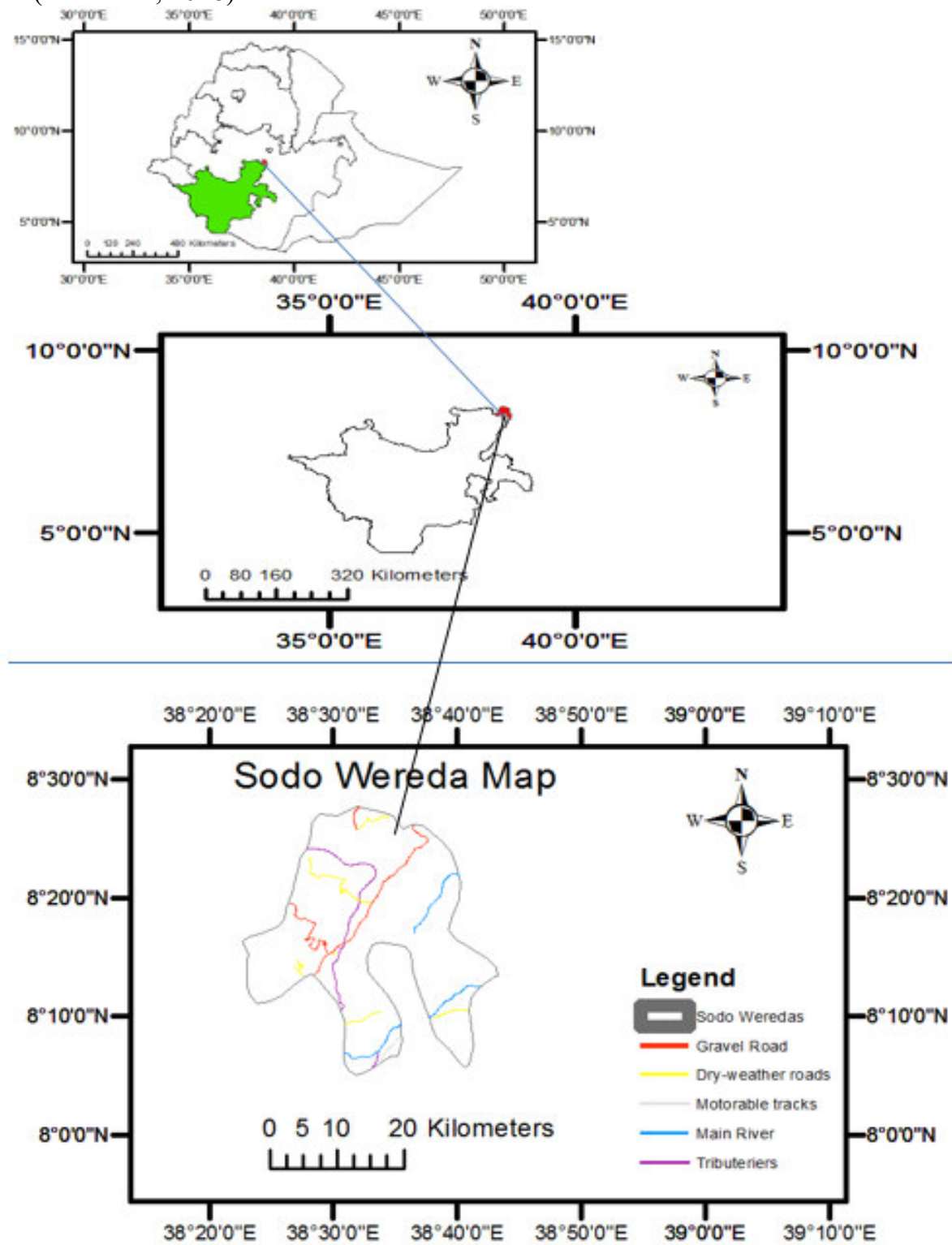

Figure 2 Location Map of Study Area

Source: SWAO 


\subsection{Research Design}

The research design for this study was cross-sectional survey type that was employed the mixed approach of both quantitative and qualitative design. The main reason for this, the study had both quantitative and qualitative data throughout the study objectives.

\subsection{Sampling Technique}

In order to collect well-built data needed to achieve the objectives of the research, a multi-stage stratified sampling technique was employed. In the first stage kebeles were stratified in to farest and nearest kebeles; after putted them in order of relative number participants households in microfinance priogram six target kebeles were selected out of 54 kebeles through systematic simple random sampling method. Accordingly, Adele Chelelek, Buee zuria, Genbela, Goget1, Wacho Moreghe and Wudgetna Gefersa were selected.

In the second stage, the numbers of households in the selected kebeles were stratified in to strata of participants and non-participants in order to select representative sample households. Accordingly, Adele Chelelek kebele consisting of $1052 \mathrm{HHs}$ and 80 participants, Buee zuria kebele consisting of $494 \mathrm{HHs}$ and 93 participants, Genbela kebele consisting of $591 \mathrm{HHs}$ and 135 participants, Gogetil kebele consisting of $475 \mathrm{HHs}$ and 108 participants, Wacho kebele consisting of $489 \mathrm{HHs}$ and 119 participants and Wudgetna gefersa kebele consisting of $491 \mathrm{HHs}$ and 84 participants were considered, which make a total population of $3592 \mathrm{HHs}$ and 619 of them were participants. In the third stage households who have been participants of OMFI microfinance program for five and more subsequent years were identified from the list they belong in each kebeles. Accordingly 260 participants were identified.

To identify sample size for the study, rule of thumb suggested by Green (1991) was followed. He suggests that, $n \geq 50+8 m$ (where $n$ is sample size of the study and $m$ is a number of independent variables). The study had twelve independent variables therefore, the sample size for this study should be greater than or equal to 146 . But the sample size for study was 190 in order to get enough number of match groups. In the fourth stage a representative sample was selected through systematic simple random sampling method from both strata of participant $\geq 5$ years and non-participant households. Then a total of 190 (80 participants and 110 non-participants households) were drawn. The sample size of each kebeles was determined based on probability proportional to size sampling method.

Table 1: distribution of sample households and sample kebeles

\begin{tabular}{llllllll}
\hline Sample kebele & $\begin{array}{l}\text { Total } \\
\text { household }\end{array}$ & \multicolumn{3}{l}{ Participant household } & \multicolumn{2}{l}{$\begin{array}{l}\text { Non-participant } \\
\text { household }\end{array}$} & $\begin{array}{c}\text { Total } \\
\text { sample }\end{array}$ \\
\cline { 3 - 7 } & & Total & $\begin{array}{l}\text { Total } \\
(>=5 \mathrm{yr})\end{array}$ & Sample & Total & Sample & \\
\hline Gogeti one & 475 & 108 & 42 & 13 & 367 & 13 & 26 \\
Buee zuria & 494 & 93 & 45 & 14 & 401 & 15 & 29 \\
Genbela & 591 & 135 & 56 & 17 & 456 & 17 & 34 \\
$\begin{array}{l}\text { Adele chelelek } \\
\text { Wacho morege }\end{array}$ & 1052 & 80 & 32 & 10 & 972 & 36 & 46 \\
$\begin{array}{l}\text { Wudgetna } \\
\text { gefersa }\end{array}$ & 499 & 119 & 41 & 13 & 370 & 14 & 27 \\
\hline Total & 34 & 44 & 13 & 407 & 15 & 28 \\
\hline
\end{tabular}

\subsection{Data Source and Methods of Data Collection}

Both primary and secondary sources were used to collect the required data for this study to meet the research objectives. Primary data were collected from the sampled households through structured interview. Focus Group Discussion and Key Informants were also used to collect through semi-structured interview and checklists. Secondary data were collected from websites, articles, research works, and review of related literatures while taking the research objectives into account.

\subsubsection{Primary data collection}

The primary data were collected through household survey, focus group discussion, and key informant interview. 1. Household Survey

After drawn sampled households in each selected kebeles, interview schedule method was applied to collect primary data from sampled households through structured interview with open and close ended questions. The information was focused on livelihood of rural HHs' in general and income and asset holding of rural HHs' in particular. The household survey was conducted by trained interviewers after pre-testing the questionnaires.

\section{Focus Group Discussions (FGDs)}

Discussions focus on the research issues were carried out among groups. There were a total of six FGDs at each kebeles. Those who were included in FGDs were not included in interview schedule. To guide the discussion, 
semi-structured checklists were designed specific to the research issues. It was conducted by the researcher and he had acted as facilitators.

\section{Key Informants Interview}

This was employed to gather information in depth related with study objectives. Based on this, different sectors concerned with the study issue were participated in giving the required information. Namely, each kebele leader and kebele manager, OMFI agents, OMFI expert, public relation officer and manager, model farmers and Woreda administration public relation officer were included as key informants. It was conducted by the researcher.

\subsubsection{Secondary data collection}

Collection of data from secondary sources is also important in research. Government agencies, Non-Government Organizations (NGOs), different research works and other related processes in the CBOs of study areas in the form of project reports, evaluation reports, and several books and internet/websites were used as a source of secondary data.

\subsection{Methods of Data Analysis}

Both descriptive statistics and inferential statistics were used to analyze the collected data. The data collected from focus group discussion and key informant interview were analyzed by narration.

\subsubsection{Descriptive statistics}

Descriptive analysis were used to reduce the data in to a summary format by tabulation (the data arranged in a table format) and measure of central tendency (mean) measure of variance (standard deviation), percentage and frequency distribution, chi-square and t-test statistics were utilized. Analysis was made using through statistical package for social studies (SPSS) version 20 used for descriptive statistics and Microsoft Excel 2010.

\subsection{Definition of Variables and Hypothesis}

It is important to define the study variables and their measurement as well as the symbols representing them. Based on the review of literatures the following potential explanatory variables were considered in this study which affects both the participation and outcomes of interests. Accordingly, different demographic, socio-economic and institutional factors were identified below.

\subsubsection{Dependent variable}

The dependent variable was used in the PSM estimation has a dichotomous nature representing rural household's participation in microfinance program. This is to distinguish between those participants or non-participants of OMFI in the study area. It takes value of " 1 " for participants " 0 " for non-participants.

\subsubsection{Independent variables}

The main hypothesis is that access to microfinance institutions (MFIs) increase rural households' income and asset holding. Based on this main hypothesis, the following potential variables were hypothesized to influence the aforementioned dependent and outcome variables.

Age of household head (AGE): It is a continuous variable, defined as the rural household head age at the time of interview measured in years. Those households having a higher age due to life experience would have much better association with cooperatives and other formal credit institutions, and it was hypothesized that households with higher age may have more access to microfinance program.

Sex of household heads (SEX): It is a dummy variable which is believed to influence the decision to be a member of MFI and to utilize its services. Female-headed households may face some cultural barriers in dealing with the cash economy and lack of control over economic resources (Minot et al., 2006). Including the existing gender differences, male headed households have mobility, participate in different meetings and have more exposure to information. The decision of participation in MFIs by female headed households is lower as compared to male headed households (Mahlet, 2005). Hence, it was hypothesized that male headed households have more access to different sources of formal credit and saving institution.

Family size (FAMSZE): It is continuous variable that refers to the number of family members' of a given household. The existence of large number of family members with limited resources could affect the status of the household income. For instance, (Croppensted et al. 2003) argue that households with a larger pool of labor should be more likely to adopt agricultural technology which demands financial resource to afford it and use it more intensively because they have fewer labor shortages at peak times. Therefore, household with larger number of family was expected to be positively correlated being participant in microfinance program.

Education level of household heads (EDULVEL): It is a continuous categorical variable that refers to the human capital development, measured by level of grade finished (schooling year) and in this study it categorized in to: $0=$ unable to read and write, $1=$ can read and write, $2=$ grade $1-4^{\text {th }}, 3=5-8^{\text {th }}$ and $4=9^{\text {th }}$ and above. Households' who have educated more will have higher awareness on the possible advantages of microfinance participation to engage in income generating non/off-farm activities and widen their livelihood means's. In addition to this more educated household is expected to have more exposure to farming technologies and information. Furthermore respondents who attain education would have high bargaining power on the decision of the household income. From this it is 
possible to say that households who are literate were expected to being participant in microfinance program and would have high (positive) involvement in the decision of the household income (Edith's 2009). Therefore, it was expected that education level of rural households' increased being participant in microfinance program.

Frequency of extension contact (FEXTCON): It is a continuous variable which is measured by numbers of days they contact with DAs and OMFI agent within a year. The frequency of rural households contact with development agent increases, they get information about how to increase their farm income and get engaged in different nonfarm activities which supplement their farm income (Sisay, 2013). It was expected that frequency of extension contact increase rural households' being participant in microfinance program.

Farm land size (LANDSIZE): This refers to the total arable farm land that a household owns measured in hectares. Many agricultural innovations require substantial economic resources of which land is the principal one. Large land holder households are considered as safe clients by the lending institution, as they have potential to produce more which helps them to repay back loan (Abera, 2015). Hence, in this study households those who have large farm land size was expected to positively correlate with participation in microfinance program.

Number of dependents (NOD): This is a continuous variable which indicates the number of dependent members on household's income. In this study numbers of dependent members include the number of children and other relatives and elder ones who depend on a given household's income for their livelihood and their age is below 14 and above 64 who cannot participate in any job activity. It is expected that the higher the number of dependents, the greater the fear of diverting loan to meet household obligations and the less the participation in the microfinance program. And this variable was expected to associate negatively with household's participation in microfinance program.

Perception of Risk (RITAKE): The other factor, which influences the household's access to microfinance program, is their attitude on risk of default. Many farmers, as can be expected, are very risk-averse that even when credit is available, they do not like to venture into activities. This is due to risks of repaying loans that come from loss of business due to seasonal changes, pest and insect damage (Sisay, 2006). It will be measured based on the farmer's positive or negative perception. This is a dummy variable which takes " 1 " if they respond as they don't fear risk of default to take loans and " 0 " otherwise. Therefore, it was expected that households who are risk averse were not demand microfinance program and it negatively affects access to use microfinance program of OMFI.

Participation in non-farm activities (PRTNONF): This is dummy variable, which takes a value "1" if the household was involved in non-farm activities and 0 , otherwise. Non-farm activities generate additional sources of income for households but needs extra budget to run the non-farm activities. Katsushi and Thankom (2008) found that availability of non-farm business in rural area of India increases the probability of rural households' participation in MFIs. Therefore, participating in non-farm activity was hypothesized to have positive influence on households to participate in OMFI microfinance program and outcome variables.

Size of loan (LOANSZE): In principle, borrowers are expected to propose loan size along with loan purpose. Sisay (2013) found that adequate size of loan was positively and significantly related to the probability of income incremental of clients which means that households who took relatively large size of loan enjoyed increment of their income and inadequate loan size being constraint and it was difficult to participate in the program. It is hypothesized that the loan size of OMFI influences the household participation in OMFI and outcome variables negatively. This variable is a dummy variable which takes a value "0" for those who perceive loan size is inadequate and a constraint to participate in OMFI microfinance service and "1"for those who perceived it is adequate and not a constraint to participate in OMFI microfinance program.

Procedures of application for credit (PRODRAPP): To get loan from OMFI microfinance service, households are expected to pass through different processes (group forming, support letter from Kebele administration, etc.), which are time-taking and cumbersome. This variable represents the borrower's perception of difficulty of the lending procedure (Hussien, 2007). It is a dummy variable which takes a value " 1 " for those who perceive procedure of application for credit is as a constraint to participate in OMFI microfinance service and " 0 " for those who perceived it is not a constraint to participate in OMFI microfinance service. Hence, this variable was assumed to have negative influence participation of households in OMFI microfinance service and the outcome variables.

Distance from office of OMFI office (DSOMFI): is a continuous variable measured by hour taken to travel from their residence to office of OMFI and also shows farmers location nearness to OMFI office. Proximity to office is an important factors influencing rural households' participation presumably because contact the lender easily and have more access to information than those who live more distant locations. Hence, being farther location from the office of institution decreases the probability of lender information and microfinance program access (Ferdissa, 2012). Another study conducted by Sisay (2013) found that distance was one of the limiting factors to access credit from OCSSCO microfinance. It was expected that being far from office of OMFI limit being participant in microfinance program. 
Table 2: Types, symbol and measurement of variables

\begin{tabular}{|c|c|c|c|c|}
\hline Variable & Symbol & Type & Measurement & $\begin{array}{l}\text { Expected } \\
\text { relation }\end{array}$ \\
\hline \multicolumn{5}{|l|}{ Dependent variable } \\
\hline Participation in OMFI & PARTOMFI & Dummy & 1 if yes, 0 otherwise & \\
\hline \multicolumn{5}{|l|}{ Independent variable } \\
\hline Age of sample households & AGE & Continuous & In years & + \\
\hline Sex of sample households & SEX & Dummy & 1 if male, 0 otherwise & $+/-$ \\
\hline $\begin{array}{l}\text { Education level of sample } \\
\text { households }\end{array}$ & EDULEVL & Continuous & Schooling year & + \\
\hline Family size of household & FAMSZE & Continuous & $\begin{array}{l}\text { Total number of household } \\
\text { members }\end{array}$ & $+/-$ \\
\hline Size of farm land & FRLNSZE & Continuous & Hectare & + \\
\hline Frequency of extension contact & FEXTCON & Continuous & In days within a year & + \\
\hline $\begin{array}{l}\text { Number of dependent in the } \\
\text { household members }\end{array}$ & NOD & Continuous & $\begin{array}{l}\text { Total number of dependant } \\
\text { household members }\end{array}$ & - \\
\hline Perception on risk & RITAKE & Dummy & 1 if yes, 0 otherwise & $+/-$ \\
\hline Participation in non-farm activity & PRTNONF & Dummy & 1 if yes, 0 otherwise & + \\
\hline Perception Size of loan & SIZLOAN & Dummy & 1 if yes, 0 otherwise & $+/-$ \\
\hline Procedure of application & PRODAPP & Dummy & 1 if yes, 0 otherwise & $+/-$ \\
\hline $\begin{array}{l}\text { Distance of households' } \\
\text { residential from office of OMFI }\end{array}$ & DSOMFI & Continuous & Hours (travel time) & - \\
\hline
\end{tabular}

Source: Own definition, (2016)

\section{RESULTS AND DISCUSSION}

\subsection{Demographic characteristics of sample households}

Family size: Table 4 shows the family size, number of dependent members and age of the sample household heads. Accordingly, family size of the sample respondents ranges from 3 to 12 persons. The average family size of the participants and the non-participants households was 7.94 and 7.16 with a standard deviation of 2.06 and 2.16 respectively. The mean difference was statistically significant at 5\% level of significance (Table 3 ) which might indicate that larger family size in households have enough labor force which demand working capital and they might be participant in OMFI microfinance program to fulfill their financial requirement.

Number of dependent household members: Dependent household members are those whose age is either less than 14 or greater than 64 years. The maximum and the minimum of number of dependents in the household members were 7 and 1 respectively. Participants had on average 2.34 with a standard deviation 1.09 while nonparticipants had on average 3.10 with a standard deviation 1.26 . The mean difference was statistically significant at $1 \%$ level of significance (Table 3 ). This might indicate that number of dependents members in the household limit the participation of households in OMFI microfinance program.

Age of respondents: The maximum and minimum age of total sample households were 23 up to 64 and the mean age was 48.30 years with a standard deviation of 11.78 . The average age of participants and non-participants was 49.35 and 47.29 years with standard deviation of 9.71 and 13.04 respectively. Even though, there was mean difference between participants and non-participants, it was statically insignificant (Table 3 ).

Table 3: Sample households by age and family size

\begin{tabular}{|c|c|c|c|c|c|}
\hline \multirow[t]{2}{*}{ Characteristics } & $\begin{array}{l}\text { Participant } \\
(\mathrm{N}=80)\end{array}$ & $\begin{array}{c}\text { Non-participant } \\
(\mathrm{N}=110)\end{array}$ & Difference in mean & $\mathrm{t}$-value & $\begin{array}{r}\text { Total Sample } \\
(\mathrm{N}=190)\end{array}$ \\
\hline & Mean(SD) & Mean(SD) & $\operatorname{Mean}(\mathrm{SD})$ & & $\operatorname{Mean}(\mathrm{SD})$ \\
\hline Age (years) & $49.35(9.71)$ & $47.29(13.04)$ & $2.06(3.33)$ & 1.15 & $48.30(11.78)$ \\
\hline Maximum & 64 & 76 & & & 76 \\
\hline Minimum & 23 & 24 & & & 23 \\
\hline Family size & 7.94(2.06) & $7.16(2.16)$ & $0.78(0.10)$ & $2.49 * *$ & $7.55(2.15)$ \\
\hline Maximum & 12 & 12 & & & 12 \\
\hline Minimum & 3 & 3 & & & 3 \\
\hline $\begin{array}{l}\text { Numbers of dependent } \\
\text { members }\end{array}$ & $2.34(1.09)$ & $3.10(1.26)$ & $-0.76(-0.17)$ & $-4.35 * * *$ & $2.77(1.25)$ \\
\hline Maximum & 6 & 7 & & & 7 \\
\hline Minimum & 1 & 1 & & & 1 \\
\hline
\end{tabular}

Source: Own survey result (2018)

$* * *$ and $* *$ means significant at $1 \%$ and $5 \%$ level of significance respectively 
Sex of sample respondents: Of the total respondents, $87.9 \%$ and $12.1 \%$ were male and female headed households respectively. Male headed households were account $85 \%$ and $90 \%$ of participants and non-participants whereas female headed households were represents $15 \%$ and $10 \%$ of participants and non-participants respectively. Even though there was a difference in percentage among the two groups, it was statistically insignificant (Table 4).

Marital status and Religion of sample respondents: from the total sample household; $92.6 \%$ of married, $1.1 \%$ of divorced and $6.3 \%$ of them were widowed. About $97.5 \%$ and $2.5 \%$ of the participants' households were married and widowed respectively while $89.1 \%, 1.8 \%$ and $9.1 \%$ were married, divorced and widowed of the nonparticipants respectively. The Chi square value of 4.994 was significant at $10 \%$ probability level of significance (Table 4). With considering religion of the total respondents were $93.7 \%$ and $6.3 \%$ Orthodox and protestant which constitute $87.5 \%$ and $12.5 \%$ of the participant respondents while $98.2 \%$ and $1.8 \%$ were constitute the nonparticipant respondents respectively.

Educational level of the sample respondents: With regard to educational level about $17.5 \%, 27.5 \%, 41.2 \%, 8.8 \%$ and $5 \%$ of participant sample respondents were unable to read and write, can read and write, $1-4^{\text {th }}, 5-8^{\text {th }}$ and $9^{\text {th }}$ and above respectively whereas non-participants sample represent $25.5 \%, 39.1 \%, 27.3 \%, 6.4 \%$ and $1.8 \%$ were unable to read and write, can read and write, $1-4^{\text {th }}, 5-8^{\text {th }}$ and $9^{\text {th }}$ and above respectively. Thus, there was a significant difference (10\% level significance) between participant and non-participant groups with regards to the education level of respondents. This might indicate that more educated households have high chance being participant in OMFI microfinance program, ceteris paribus.

Table 4: Sample households by sex and level of education

\begin{tabular}{|c|c|c|c|c|c|c|c|c|}
\hline \multirow[t]{2}{*}{ Characteristics } & & \multicolumn{2}{|c|}{$\begin{array}{l}\text { Participants } \\
(\mathrm{N}=80)\end{array}$} & \multicolumn{2}{|c|}{$\begin{array}{l}\text { Non-participants } \\
(\mathrm{N}=110)\end{array}$} & \multirow[t]{2}{*}{$\chi^{2}-$ Value } & \multicolumn{2}{|c|}{$\begin{array}{l}\text { Total sample } \\
(\mathrm{N}=190)\end{array}$} \\
\hline & & $\mathrm{N}$ & $\%$ & $\mathrm{~N}$ & $\%$ & & $\mathrm{~N}$ & $\%$ \\
\hline Sex of sample & Male & 68 & 85 & 99 & 90 & \multirow[t]{3}{*}{1.088} & 167 & 87.9 \\
\hline households & Female & 12 & 15 & 11 & 10 & & 23 & 12.1 \\
\hline Marital status of & Married & 78 & 97.5 & 98 & 89.1 & & 176 & 92.6 \\
\hline sample & Divorced & 0 & 0 & 2 & 1.8 & \multirow[t]{2}{*}{ 4.994* } & 2 & 1.1 \\
\hline households & Widowed & 2 & 2.5 & 10 & 9.1 & & 12 & 6.3 \\
\hline Religion & Orthodox & 70 & 87.5 & 108 & 98.2 & \multirow[t]{2}{*}{$8.932 * * *$} & 178 & 93.7 \\
\hline $\begin{array}{l}\text { sample } \\
\text { households }\end{array}$ & Protestant & 10 & 12.5 & 2 & 1.8 & & 12 & 6.3 \\
\hline \multirow{5}{*}{$\begin{array}{l}\text { Educational level } \\
\text { of sample } \\
\text { households }\end{array}$} & $\begin{array}{l}\text { Unable to read } \\
\text { and write }\end{array}$ & 14 & 17.5 & 28 & 25.5 & \multirow{5}{*}{$7.37^{*}$} & 42 & 22.1 \\
\hline & $\begin{array}{l}\text { Can read and } \\
\text { write }\end{array}$ & 22 & 27.5 & 43 & 39.1 & & 65 & 34.2 \\
\hline & $1-4^{\text {th }}$ & 33 & 41.2 & 30 & 27.3 & & 63 & 33.2 \\
\hline & $5-8^{\text {th }}$ & 7 & 8.8 & 7 & 6.4 & & 14 & 7.4 \\
\hline & $9^{\text {th }}$ and above & 4 & 5 & 2 & 1.8 & & 6 & 3.2 \\
\hline
\end{tabular}

Source: Own survey result (2018)

$* * *$ and $*$ means significant at $1 \%$ and $10 \%$ level of significance respectively

\subsubsection{Socio-economic and institutional characteristics of the sample households}

Land holding: Land is a vital resource to rural households. The average size of land owned by the total sample house was 2.58 ha, with 0.25 ha being the minimum and 9.5 ha being the maximum land holding. The mean size of land hold by participants was 2.84 ha and non-participants hold 2.36 ha. The result of the study indicated that participants hold, on average, a larger area of land than non-participants and the mean difference of size of land holding between participant and non-participant was statistically significant at $1 \%$ level of significance which might show that the size of land holding was one the factors affecting participation in OMFI microfinance program and those who have large farm land size have the probability of being participant, ceteris paribus (Table 5).

Table 5: Sample households by farm land size (ha)

\begin{tabular}{llllll}
\hline & Participant & Non-participant & Difference & t-value & Total sample \\
\cline { 2 - 6 } Characteristics & $(\mathrm{N}=80)$ & $(\mathrm{N}=110)$ & in means & $(190)$ \\
\hline & Mean(SD) & Mean(SD) & Mean(SD) & Mean(SD) \\
Farm land size & $2.84(1.52)$ & $2.36(1.08)$ & $0.48(0.44)$ & $2.69 * * *$ & $2.58(1.34)$ \\
Maximum & 9.5 & 7.75 & & 9.5 \\
Minimum & 0.5 & 0.25 & & 0.25 \\
\hline
\end{tabular}

Source: own survey result (2018)

*** means significant at $1 \%$, and $5 \%$ level of significance respectively

Frequency of extension contact: There are three to four development agents (DAs) and Omo microfinance institution (OMFI) agent at each kebele to provide frequent technical assistance and advisory service to rural 
households in order to improve production and productivity. The important question is not whether they access extension contact or not but the important question is the frequency of they have contact with development agent. The frequency of the total sample households had contacted with DAs within a year, on average, was 8.16 days with a standard deviation 4.21 and the participant and non-participant respondents had contacted with DAs within a year, on average, were 9.64 days with a standard deviation 4.21 and 7.09 days with a standard deviation 3.68 respectively. The mean difference was statistically significant at $1 \%$ level of significance in terms of frequency of extension contact days per year between the two groups (Table 6). This might indicate that households those who contact with DAs and omo agent frequently have the probability being participant in OMFI microfinance program. Table 6: Distribution of sample households by frequency of extension contact and distance of households' residence from office of OMFI

\begin{tabular}{|c|c|c|c|c|c|}
\hline \multirow[t]{2}{*}{ Characteristics } & $\begin{array}{l}\text { Participant } \\
(\mathrm{N}=80)\end{array}$ & $\begin{array}{l}\text { Non- } \\
\text { participants } \\
(\mathrm{N}=110)\end{array}$ & $\begin{array}{l}\text { Difference in } \\
\text { mean }\end{array}$ & t-value & $\begin{array}{l}\text { Total } \\
\text { sample } \\
(\mathrm{N}=190)\end{array}$ \\
\hline & Mean(SD) & Mean(SD) & Mean(SD) & & Mean(SD) \\
\hline $\begin{array}{l}\text { Frequency extension contact in } \\
\text { days within a year }\end{array}$ & $9.64(4.21)$ & $7.09(3.68)$ & $2.55(0.53)$ & $4.78 * * *$ & $8.36(4.10)$ \\
\hline Maximum & 20 & 20 & & & 20 \\
\hline Minimum & 3 & 0 & & & 0 \\
\hline $\begin{array}{l}\text { Distance from home to office of } \\
\text { OMFI (hrs) }\end{array}$ & $3.91(1.35)$ & $4.37(1.47)$ & $-0.46(-0.12)$ & $-2.36^{* *}$ & $4.17(1.44)$ \\
\hline Maximum & 6 & 6 & & & 6 \\
\hline Minimum & 1 & 1 & & & 1 \\
\hline
\end{tabular}

Source: Own survey result (2018)

$* * *$ and $* *$ means significant at $1 \%$ and $5 \%$ level of significance

Distance of households' residence from OMFI office (hours): The result of the study indicated that the average distance travelled in hours by the available transport including on foot by the total sample households was 4.17 hours with a standard deviation 1.44 while the average distance travelled in hours by participant and nonparticipant respondents were 3.91 hours with a standard deviation 1.35 and 4.37 hours with a standard deviation 1.47 respectively. The mean distance travelled by participants was lower than non-participants and it was statistically significant at 5\% level of significance in terms of distance travelled in hours between the two groups (Table 6). This might indicate that distance of households residential from office of OMFI limit rural households' being participant in OMFI microfinance program.

\subsubsection{Determinants of rural households' participation in OMFI microfinance program}

This sub-part presents the result of the logistic regression model which was used to identify the factors that determine rural households' participation in OMFI microfinance program since the dependant variable in this model was a binary variable indicating whether the household had participated in microfinance program of OMFI or not. In the estimation, data from both groups namely participant and non-participant were collected such that the dependant variable takes a value of " 1 " for participant and " 0 "for non-participant. However, before fitting the logit model, it was important to check whether serious problem of multicollinearity and heteroscedasticity. Multicollinearity was tested using variance inflation factors (VIF). Accordingly, the result of VIF showed that the data had no serious problem of multicollinearity (Appendix Table3). Heteroscedasticity was tested using BreuschPagen test which is significant at $1 \%$ probability level $(0.002)$ and it indicate that there was heteroscedasticity problem which suggest standard error robust. Hence, there was conducted standard error robust accordingly.

Accordingly the estimation results of the logit model showed that family size (FMLSZE), education level (EDULEVEL) and frequency of extension contact per year (FEXTCON) were significant factor influencing rural households' participation in OMFI microfinance program positively while number of dependent members of household (NOD), perception of risk (RITAKE), distance of households' residence from office of OMFI (DISOMFI) and application procedure for credit from OMFI (PRODRAPP) were significant factors that limit the participation of rural households in OMFI microfinance program. Possible explanations for each significant explanatory variable are given as follows.

Family size (FAMSZE) was found to be important variable in rural households' participation in microfinance program. The estimated parameters were positive and significant at $1 \%$ level of significance (Table 17). This positive relationship shows that the probability of being participant in microfinance program increased with increase in family size. On the other hand, large number of households has more labor force available for production which demands more credit. The odds ratio indicates that, other things remain constant; the probability of being participant increases by a factor of 1.309 as family size increases by one person. This finding is consistent with previous studies which revealed that having a bigger family, ceteris paribus, increased the demand for loans, because per capita income was smaller for big households so as to expect a large flow of income in the future to 
begin to work, thus they were likely to demand more credit (Sisay, 2013; Syeda et al., 2008).

Number of dependents (NOD): This variable as hypothesized it has a negative influence on rural households' participation in microfinance program. The estimation result indicates that number of dependent members is found to be negatively correlated with the dependent variable and it was significant at $1 \%$ level of significance (Table 17). Here as the odd ratio indicates; the probability of being participant decrease by a factor of 0.521 as number of dependent members in household increase by one person, ceteris paribus. This study also consistent with a study conducted by Sisay (2013) which indicated that the number of dependant (economically inactive) family members increases, the demand for working capital become low because majority of the household members are dependant so as to carry out farm/non-farm activities independently.

Educational level of Respondents (EDULEVL): The estimation result indicates as there is positive relationship between educational level of the respondents and being participant in microfinance program. And this is significant at $1 \%$ level of significance (Table 17). The odds ratio indicates that, other things remain constant; the probability of being participant in microfinance program increases by a factor of 2.521 as household education increased by one schooling year. This finding also convenient with Edith's (2009), research findings he indicated as literate households have more willingness (demand) to participate in microfinance program, to take loan for better production technologies, engaged in non-farm activities, purchase agricultural inputs, purchase fixed household asset, improve houses, accept technical advice from extension workers and have awareness regarding opportunities and expectation for decision making purpose and diversifying their source of income than the illiterate ones.

Frequency of extension contact (FEXTCON): It is also one of the variables which significantly important for rural households' participation in microfinance program (at 1\% level of significance). It was hypothesized and found that households' who have frequent contact with extension and OMFI agents were expected to have more aware about new technologies, how to increase production and productivity, and the merit and demerit of formal credit and saving institution which influence rural household's demand to use credit and saving from the formal sources.. As hypothesized, the estimation result indicates that it was positively affect the participation of rural households' ceteris paribus, as the odd ratio indicates frequency of extension contact in favor to increase rural households' participation in microfinance program by a factor of 1.105 for increasing extension contact a day per year (Table 17). This finding supported the studies of Klimpo (2013) and Sisay (2013) improving extension services contribute to participation of smallholder farmers in microcredit

Perceptions of risk (RITAKE): It was hypothesized that perceptions of risk have negative relationship with rural households' participation in microfinance program; this is because of the fact that those respondents who have averted towards taking risk due to unexpected situation (market price and weather variability, occurrence of pesticide and disease, so on) might have damaged their business operated by loan. Therefore, during occurrence of risk they might incur lose their asset to repay their debt (Sisay, 2006; Bigsten et al., 2003). As a result, they fear to participate in microfinance program. It was significant at $1 \%$ level of significance (Table 17) and the odd ratio indicates that the probability of being participant in microfinance program decrease by a factor of 0.219 for those who avert risk of default, holding other things constant.

Distance of households' residence from office OMFI (DISOMFI): This variable was hypothesized and found to influence rural households' participation in MFIs negatively and significantly at 5\% level significance (Table 17). The odds ratio is in favor of the probability of being participant in microfinance program decrease by a factor of 0.804 for those live in far place than the nearer as the distance travelled increased by an hour, ceteris paribus. With regard to this, Ferdissa (2012) also indicated as the non-proximity and non-accessibility of road in the area could take time and increase cost to transport farm inputs and farm products from and to the market. The proximity of road can reflect access to get inputs easily and transport farm products to the market quickly with little post harvest losses.

Procedure of application for credit (PRODURAP): This variable was found to influence negatively and significantly (at $5 \%$ level of significance) the participation of households in microfinance program (Table 17). This might be due to the fact that to get loans from OMFI, households expected to pass through different processes (group formation, support letter from Kebele administration, etc.) which is time taking and burdensome. Moreover, some of the households were facing problems to form a group because others do not want them in their group due to fear of risk in case of default and shock. If a single individual defaults, all the members of the kebele were denied access to the next round of loan till repaid. The odd ratio indicates that procedure of application for credit limit rural households being participant in OMFI microfinance program by factor of 0.922 for those perceived the difficulty of procedure of application for credit, ceteris paribus. This finding is consistent with the finding of Sisay (2013) and Hussein, (2007) which revealed that lending procedure is perceived as difficulty and constraint to access credit from formal credit source. The information obtained from FGD's of Genbela kebele supported this finding.

"Almost all member of their kebele (Genbela) replied the credit, but they are denied access to next round loan due to a single person was indebted. Now the time (April) was the time to purchase different input (improved variety (maize), fertilizer, ox, etc) for autumn season. Therefore, the system and the bureaucratic procedures demoralize 
and humiliate them".

\section{SUMMARY, CONCLUSION AND RECOMMENDATIONS}

\subsection{Summary}

This study was conducted to identify the factors affecting rural households' participation in microfinance program and its impact on their income and asset holding in Sodo woreda. A multi-stage stratified sampling technique employed to draw sample respondents. The study utilized both primary and secondary data. The primary data were collected from 80 microfinance program participants who have at least five years participation status in OMFI and 110 non-participant households who hadn't being participant yet in microfinance program from OMFI using a structured interview schedule.

Demographic characteristics, socio-economic condition, institutional characteristics, living condition, perception of risk, application procedure for credit and loan size of OMFI were analyzed using descriptive statistics. The result of descriptive statistics revealed that there were significant mean and proportional difference among participant and non-participant households in terms of frequency of extension contact, distance of households' residences from OMFI office, family size, level of education, number of dependent member, perception of risk, perception on application procedure for credit, and

\subsection{Conclusion}

Microfinance intervention is taken as a strategy to overcome the constraints of convectional bank and it is seen as one of the most efficient instrument to promote economic development, livelihood improvement and diversification and infighting poverty among rural households. It also provides collateral free credit/loan to rural households that rural households were lack previous rural development paradigms.

Family size, level of education and frequency of extension contact were significantly and positively influence the participation of rural households in OMFI microfinance program which number of dependent members, application procedure for credit, perception of risk and distance of rural households residence from office of OMFI were significantly limits the participation of rural households in OMFI microfinance program.

\subsection{Recommendations}

The finding of this study revealed that extension contact is an important factor that enhances the rural households to participate in OMFI microfinance program and thereby improve their livelihood. It is, therefore, important that more attention should be given to contact with extension agents to create awareness of rural households. Moreover, extension and OMFI agents should pay attention to advice households on how they can improve their income as well as their livelihood by directing them from where they can get working capital.

Education level is found the important factor that enhances rural households being participant in OMFI microfinance program. Rural households should access education nearby their village. Therefore, the government and other stakeholders should strength, expand and monitor adult teaching program.

Application procedure for credit is found one of an important factor which influenced negatively the participation of rural households in OMFI microfinance program. Moreover, during group discussion, most of the respondents replied that the application procedure for credit by OMFI was not suitable and there were complex rule and regulation (for example, if a team or a single person was indebted in the kebele; the whole households' of the kebele denied access of microfinance program particularly credit). Therefore, OMFI, government and others stakeholders should reduce bureaucratic procedure and make working structural easy, smooth and efficient to attract rural households to participate in OMFI microfinance program.

The study has found that fear of risk of default in accessing loan was the factor that has been limits rural households participation in microfinance program. Therefore, OMFI should give more emphasis to create awareness of rural households associated with this problem and how they utilize the loans, to be productive and profitable. Moreover, OMFI, government and other concerned stakeholders' should develop risk minimizing system and provide necessary input to overcome risk bearing factors.

The information obtained from FGDs indicates that lending and repayment policy was also constraint that has limited rural households' participation in microfinance program. Therefore, OMFI should revise the policy on lending procedure, loan size and repayment period. In addition, OMFI should deliver loan timely and within short period of time up on the request and, the institution work hard to attract and satisfy the need and interest of borrowers.

Distance of rural households' residential from OMFI office also found to be an important factor which limit the participation of rural households in OMFI microfinance program. Therefore, OMFI, governmental organization and other stakeholders expand the proximity of infrastructure. And also the institution should give expeditious, efficient and responsive service to those who demand their program which save time and reduce transaction cost. 


\section{REFERENCES}

Abebe Tiruneh, 2006 Impact of Microfinance on poverty reduction in Ethiopia: The cases of three branches of Specialized Financial and Promotional Institution (SFPI), Master Thesis, Addis Ababa University: Addis Ababa, Ethiopia.

Abera alemu, 2015. Impact of Microcredit on Selected Livelihood Assets of Rural Households: The Case of Shebedino Woreda Omo Microfinance Institution, Sidama Zone. M.Sc. Thesis, Hawassa University, Ethiopia

Achamyeleh Tamiru, 2011. Microfinance: Does it support households to achieve an income above self-sufficiency? Evidence from rural northern Ethiopia: Norwegian University of Life Science, Norway.

Amogne Asfaw, 2014. Microfinance as a pathway out of poverty and viable strategy for livelihood diversification in Ethiopia,Wollo University, Ethiopia. Journal of Business Management and Economics 5 (6): 142-151.

Alexander F., 2011. The impact of microfinance on the livelihoods of women in rural communities: a case study of Jaman South District, Ghana.

Asian Development Bank, 2007. Effect of Microfinance Operations on Poor Rural Households and the Status of Women: Special Evaluation Study.

Asmamaw Yigzaw, 2014. The Impact of Microfinance on Living Standards, Empowerment and Poverty Alleviation of the Poor People in Ethiopia, a Case Study in ACSI. Journal of Finance and Accounting 5 (13): 43-66.

Ayalew Sida, 2014. The Role of Microfinance Institutions in Improving Livelihood; In Case of Oromia Credit and Saving Share Company In Agaro Town, Jimma Zone. European Journal of Business and Management 6(31): 376-386.

Bekele Abraham Diro and Dereje Getachew Regasa, 2014. Impact of Micro Credit on the Livelihood of Borrowers: Evidence from Mekelle City, Ethiopia. Journal of Research in Economics and International Finance, 3(1): 25-32.

Bernard, T., D. J. Spileman, Alemayehu Seyoum and Eleni Gabremadhin, 2010. Cooperatives for staple crop marketing: evidence from Ethiopia. International food policy research institute (IFPRI) research monograph.

Bigsten, A., P. Collier, S. Dercon, M. Fafchamps, B. Gauthier, J.W. Gunning, A. Oduro, R. Oostendrop, C. Patillo, M. Soderbom, F. Teal, and A. Zewfack, 2003. Credit constraints in manufacturing enterprises in Africa. Journal of African Economics, 12(1): 104-125.

Biruk Jagiso Fonke 2015 Value Chain Analysis of Bee Honey and Credit Market Participation of Bee Keepers: The Case of Damot Gale District, Southern Ethiopia M.Sc. Thesis Haramaya University, Ethiopia

Bliss, S., 2005. Microcredit, Small Loans Big Breams. United Nations, Sydney Economics Business Educators' Conference August 9, 2005.

Borchgrevik A., Tassew Weldehana and T. Weldeab, 2005. Marginalized Groups, Credit and Empowerment: The Case of Dedebit Credit and Savings Institution (DECSI) of Tigray. Occasional paper No. 14, AEMFI: Addis Ababa, Ethiopia.

Chambers R. and Conway G., 1992. Sustainable Rural Livelihoods; Practical Concepts for the 21 st Century.

Consultative Group to Assist the Poor (2013). A Guide to Regulation and Supervision of Microfinance Consensus Guideline, October 2012 Washington, DC 20433.

Croppensted A., Demeke M . and Meschi, M., 2003. Technology adoption in the presence of constraints: the case of fertilizer demand in Ethiopia. Journal of Development Economics 7 (1), 58-70.

Edith T., 2009. Micro finance, social capital and Households access to credit: evidence from Cote D'ivoire. Univeristy of Cocody-Abidjan, Cote D'ivoire.

Feigenberg B., Field E.M., and Pande, R., 2010. Building Social Capital through Microfinance. CID Working Paper No. 209, Center for International Development at Harvard University U.S.A.

Ferdissa Birru, 2012. Determinants of Small holder Farmers Participation in Microfinance and their Saving Behavior in Oromiya Region, a cross sectional approach. Forecasts, $2^{\text {nd }}$ Edition, McGraw- Hill Book Co. New York.

Getaneh Gobezie, 2007. Successes in Expanding Microfinance Opportunities in Rural Ethiopia - Where There is Little Entrepreneurship? A paper submitted for the International Finance Corporation \& Financial Times

Gilligan, D.O., J. Hoddinott and Alemayehu Syoum, 2008. The impact of Ethiopia's productive safety net programme and its linkages. Discussion paper 00839. Washington, DC: International Food Policy Research Institute.

Green, S. B. 1991. How many subjects does it take to do a regression analysis? Multivariate Behavioral Research, 26: 499-510.

Haftom Gebremeskel, 2011. A study on impact analysis of microfinance on poverty reduction. Econometrics analysis using panel data from northern Ethiopia. Master's thesis, KDI School of public policy and management, Korea.

Handa S. and J. A. Maluccio, 2008. Matching the gold standard: Comparing experimental and non-experimental evaluation techniques for a geographically targeted program Middlebury College Economics Discussion 
Paper No. 0813.

Hujer, R., M. Caliendo and S.L. Thomson, 2004. New evidence on the effects of job creation schemes in Germany. A matching approach with threefold heterogeneity. Res. Econ. 58(4), 257-302.

Hussien Hamdha, 2007. Farm household economic behavior in imperfect financial markets: doctorial thesis, Swedish University of Agricultural Sciences, Uppsala.

Johnson S. And Rogaly R., 1997 Microfinance and Poverty Reduction, Oxfam and ActionAid: Oxfam Print Unit.

Katsushi, I. and, A. Thankom, 2008. Does microfinance reduce poverty in India? Economics discussion paper series EDP-0814, Manchester.

Kilmpo, C.J., 2013. Determinants of access to credit by smallholder farmers in Eastern and Western Kenya. A M.Sc. thesis, Strathmore University, Kenya.

Khan, M.A. and Rahaman, M.A., 2007. Impact of microfinance on living standards, empowerment and poverty alleviation of poor: A case study on microfinance in the Chittagong district of Bangladesh. Master's Thesis, Umeå School of Business (USBE).

Ledgerwood J., 1999. Microfinance Handbook: an Institutional and Financial Perspective, The World Bank: Sustainable Banking with the Poor, Washington D.C.

Mahlet Abtew, 2005. Gender analysis in agriculture. Implication for agricultural extension in Alemaya woreda. M.Sc. Thesis. Alemaya University, Ethiopia.

Martha Wolday 2014. The Contribution of Microfinance Institution to the Livelihood of Micro Credit Beneficiaries: The Case of Lideta Micro-Finance Institution, Adigrat Town, Mekele University, Ethiopia.

Martina, W.P., Dagnew Gesesse, Wolday Amha, M. Rochus, D. Eric and S.William, 2008. Access to finance in Ethiopia sector assessment study. For the German technical cooperation within the engineering capacity building project, 2:12-49.

Mekonnen Yelewumwosen, 2004. The Amhara credit and saving institution (ACSI): institutional profile, current status and future strategy, Bahir Dar, Ethiopia.

Minot, N, M. Epprecht, T. Trananh and L. Q. Trung, 2006. Income diversification and poverty in the Northern Uplands of Vietnam. International food policy research institute, Washington D.C.

MIX( Microfinance Information Exchange) Markets, 2016. Microfinance in Bangladesh: http://www.mixmarket.org/mfi/country/bangladesh. Accessed on August 19/2018

Mohammad, A. K. and Mohammed, A. R., 2007. Impact of Microfinance on Living Standards, Empowerment and Poverty Alleviation of Poor People: A Case Study on Microfinance in the Chittagong District of Bangladesh.

Morduch, J and Haley B., 2004. Analysis of the effects of Microfinance on Poverty reduction. NYU Wagner working paper series no. 1014.

Otero, M., 1999. Bringing Development Back into Microfinance. Journal of Microfinance 1:1-54

Padma M. and Getachew Abate, 2005. Women economic empowerment and microfinance: a review on experiences of Awassa women clients in Gebrehiot A. (ed). AEMFI: Addis Ababa, Ethiopia.

Rahel Hurussa. 2011. Achievements and challenges of microfinance institution in Ethiopia the case of Addis Ababa, bachelor's thesis, Addis Ababa University.

Ravallion, M., 2005. Evaluating Anti-poverty programs: policy research working paper 3625, World Bank, Washington D.C.

Ravallion, M. and Q. Wodon, 2003. Evaluating Endogeneous Social Programs When Placement is Decentralized. Washington, D.C., World Bank.

Robinson M., 2007. The microfinance revolution: sustainable banking for the poor, Washington, DC: The World Bank

Rosenbaum P. R., 2002. Observational Studies $2^{\text {nd }}$ edition. New York: Springer, pp. 375.

Rosenbaum, P. R. and D.B., Rubin, 1985. Constructing a control group using multivariate matched sampling incorporating the propensity score. Journal of the American Statistician, 39: 33-48.

Rosembaum, P.R. and D.B. Rubin, 1983. The central role of the propensity score in observational studies for causal effects, Journal of Biometrika, 70(1): 41-55.

Rubin, D., 2004 Matching to Remove Bias in Observational Studies, Biometrics, third editon

Schreiner, M., 2001. Aspects of Outreach: a Framework for Discussion of the Social Benefits of Microfinance, Center for Social Development.

Shahidur R. khandker, Gayatri B. k koolwal and Hussain A. Samad, 2010. Hand book on Impact Evaluation: Quantitative Methods and Practices.

Shukran K. and Rahman F., 2011. A Grameen Bank Concept: Micro-credit and Poverty Alleviation Program in Bangladesh: International Conference on Emerging Trends in Computer and Image Processing (ICETCIP'2011) Bangkok.

Shannon, D., N. Dan, Shimeles Teffera, and B. Gilbert, 2007. Outcomes of an Ethiopian microfinance program and management actions to improve services. Journal of Microfinance, 7(1):1-17.

Shimelles Tenaw and K.M. Zahidul, 2009. Rural financial services and effects of microfinance on agricultural 
productivity and on poverty: discussion papers no: 37 , Helsinki.

Smith, J., and P. Todd, 2005. Does Matching Overcome LaLonde's Critique of Non-experimental Estimators?" Journal of Econometrics, 12(125): 305-353.

Smith, H., 1997. Matching with multiple controls to estimate treatment effects in observational studies. Journal of Sociological Methodology, 27: 325-353.

Sisay Yefru, 2013. Smallholder Farmers' Participation in Microfinance Program and Its Impact in Their Income and Asset Holding: The Case of Oromia Credit and Saving Share Company in Robe District, Arsi Zone, Oromia Region. M.Sc. Thesis Haramaya University, Ethiopia

SisayYehuala, 2008. Determinants of smallholder farmers access to formal credit: the case of Metema District, north Gondar. M.Sc. thesis, Haramaya University, Ethiopia.

Storck, H., Berhanu Adenew, Bezabih Emana, R. Begander and Getu Hailu, 1991. Management strategies for farming systems in an uncertain environment and approaches for their improvement: farming systems and resource economics in tropics, vol. 27, Wissenschaftsverag Vau Kiel KG, Germany.

SWAO (Sodo Woreda Agriculture Office), 2014. Annual report. Sodo Buee.

SWOFED (Sodo Woreda Office of Finance and Economic Development), 2014. Annual report. Sodo Buee.

SWOMFI (Sodo Woreda Omo Microfinance Institution), 2015. Background information of Omo Microfinance Institution; unpublished working paper, Sodo Buee

T. Campbell and C. Stanley, 1996. Experimental and Quasi-Experimental Designs for Research, Handbook of Research on Teaching, U.S.A.

Syeda, R. S, A. H. Amara, and T. B. Aqsa, 2008. Determinants of credit program participation and socioeconomic characteristics of beneficiaries: Evidence from Sargodh, Pakistan; pp. 2-11.

United Nation Development Program, 2014. Overview of Ethiopia. http://www.undp.org/en/country/ethiopia/overview. Accessed on December 29/2018

Wolday Amha, 2007. Managing Growth of Microfinance Institutions (MFIs): Balancing Sustainablity and Reaching Large Number of Clients in Ethiopia. Occasional Paper No. 18.

World Bank, 2015. Overview of Ethiopia. http://www.worldbank.org/en/country/ethiopia/overview. Accessed on November 19/2018

\section{APPENDICES}

\begin{tabular}{llllll}
\hline Variables & \multicolumn{1}{c}{ Coefficient } & Odds Ratio & Standard Error & $Z$ & $\mathrm{Z}>\mathrm{Z}$ \\
\hline FMSZE & $0.361 * * *$ & 1.309 & 0.117 & 3.08 & 0.002 \\
SEX & -0.194 & 0.192 & 0.626 & -0.31 & 0.781 \\
AGE & 0.013 & 1.016 & 0.021 & 0.62 & 0.565 \\
EDULEVEL & $1.303 * * *$ & 2.521 & 0.445 & 2.92 & 0.004 \\
NOD & $-0.859 * * *$ & 0.536 & 0.201 & -4.27 & 0.000 \\
LOANSZE & -0.127 & 0.864 & 0.426 & -0.30 & 0.713 \\
PRTNONF & -0.078 & 1.179 & 0.469 & -0.17 & 0.851 \\
RITAKE & $-2.044 * * *$ & 0.219 & 0.482 & -4.24 & 0.000 \\
PRODUAPP & $-0.093 * *$ & 0.922 & 0.429 & -0.22 & 0.042 \\
LANDSIZE & 0.081 & 1.054 & 0.209 & 0.39 & 0.639 \\
FEXTCON & $0.152 * * *$ & 1.105 & 0.053 & 2.85 & 0.003 \\
DISOMFI & $-0.338 * *$ & 0.804 & 0.159 & -2.13 & 0.035 \\
cons & -1.095 & 0.144 & 1.617 & -0.68 & 0.275 \\
\hline
\end{tabular}

Number of obs. $=190$, LR chi2 $(13)=105.79$ Prob. $>$ chi2 $=0.0000$

Log likelihood $=-76.422722 \quad$ Pseudo R2 $=0.4090$

Appendix Tables 1: Results of logit model

Source: Own survey result (2016)

$* * *$ and $* *$ means significant at $1 \%$ an $5 \%$ probability level of significance 
Journal of Economics and Sustainable Development

Appendix Tables 2: Variable inflation factor (VIF)

\begin{tabular}{lll}
\hline Variable & VIF & $1 /$ VIF \\
\hline FMLYSZE & 1.48 & 0.676575 \\
AGE & 1.36 & 0.733249 \\
LANDSIZE & 1.32 & 0.757384 \\
NOD & 1.27 & 0.786907 \\
RISKTAKE & 1.21 & 0.827852 \\
PRTNONFM & 1.16 & 0.864344 \\
FEXTCON & 1.14 & 0.873743 \\
LVSTK2012 & 1.14 & 0.879288 \\
EDULEVEL & 1.12 & 0.892260 \\
SEX & 1.09 & 0.913955 \\
LOANSZE & 1.08 & 0.921895 \\
DISHOME & 1.06 & 0.942115 \\
APPPROD & 1.05 & 0.950817 \\
Mean VIF & 1.19 &
\end{tabular}

Source: Own survey result 2018 